Especial: Profesores de Estudios Generales Investigan

\author{
II Sección: Docentes e investigación: tarea continua en Estudios Generales
}

\title{
Paraíso Travel y La breve y maravillosa vida de Oscar Wao: Migraciones hacia el desamparo físico y la soledad
}

\author{
Óscar Alvarado Vega \\ Universidad de Costa Rica, Costa Rica \\ oalvarado100@gmail.com \\ https://orcid.org/0000-0003-3897-0232
}

Recibido: 31 de noviembre de 2019

Aceptado: 31 de enero de 2020

Resumen: En Paraíso Travel se plantea el proceso doloroso que sufren los personajes en su viaje de migración, pero también se enfoca lo relacionado con lo que para algunos representa la casi imposible inserción en estos "nuevos mundos". La relación de amor-odio (unión-separación) que constituye la historia de Marlon y Reina, es la excusa para dar cuenta lo que significa la angustia de muchos de los migrantes en sus espacios de exclusión, mientras optan por otros espacios que tampoco les representan una verdadera salida a sus problemas de dolor y desencanto.

De igual manera, en La breve y maravillosa vida de Óscar Wao, se aborda el tema de la migración en dos direcciones: la migración espacial que lleva al personaje central de un país a otro en busca de mejores condiciones que le permitan su inserción social y una adaptabilidad mejor, en términos personales y profesionales, con el fin de desenvolverse en otra cultura al tiempo que huye "de la maldición" que aqueja a su familia. Por otra parte, manifiesta un proceso de migración interna, un rehuir de sí mismo, y de su entorno inmediato, por lo cual busca refugio

\section{(c) (i) (2) (2)}

La Revista Estudios es editada por la Universidad de Costa Rica y se distribuye bajo una Licencia Creative Commons Atribución-NoComercial-CompartirIgual 3.0 Costa Rica. Para más información envíe un mensaje a revistaestudios.eeg@ucr.ac.cr. 


\section{Especial: Profesores de Estudios Generales Investigan}

en los cómics y la producción literaria, mientras intenta ser el mejor en lo que hace, un nuevo maestro de la ciencia ficción; ello como una forma de encontrarse a sí mismo, y de interactuar de forma más adecuada con su medio y su propia personalidad.

Palabras clave: Migración, maldición, represión, aislamiento, sociedad, proceso, desencanto, miseria, paraíso, infierno

\section{Paraíso Travel y La breve y maravillosa vida de Oscar Wao: Migrations into physical helplessness and loneliness}

Abstract: In Paraíso Travel the painful process that the characters suffer in their migration trip is raised, but also the focus is related to what for some represents the almost impossible insertion in these "new worlds". The love-hate relationship (union-separation) that constitutes the story of Marlon and Reina, is the excuse to

realize what the anguish of many of the migrants means in their spaces of exclusion, while opting for other spaces that also do not They represent a real way out of your pain and disenchantment problems.

Similarly, in The brief and wonderful life of Óscar Wao, the issue of migration is approached in two directions: space migration that takes the central character from one country to another in search of better conditions that allow its social insertion and a better adaptability, in personal and professional terms, in order to function in another culture while fleeing "from the curse" that afflicts his family. On the other hand, it manifests a process of internal migration, a shun of itself, and its immediate environment, so it seeks refuge in comics and literary production, while trying to be the best at what it does, a new teacher of science fiction; this as a way to find oneself, and to interact more adequately with their environment and their own personality.

Key words: Migration; curse; repression; isolation; society; process; disenchantment; misery; paradise; hell 


\section{Especial: Profesores de Estudios Generales Investigan}

Una historia de (des)amor gira en torno a la trama que se le plantea a los personajes. La historia de Marlon y Reina es, en verdad, la excusa para la verdadera historia del texto: la migración, el dolor, la desposesión del sueño americano, la desventura del migrante. De manera cercana ocurre con la novela de Junot Díaz, en la cual la soledad de Óscar trae en el fondo la necesidad imperiosa del amor y la aceptación, ante un mundo que lo excluye.

El título en la novela de Franco resulta una clara ironía: no hay paraíso alguno más allá de las fronteras de la patria. El paraíso no existe ni en la Patria, ni fuera de ella, y la suerte del migrante es la del despojo, la del cambio que no ofrece mejoras, la de la crisis existencial, como le ocurre a Marlon y como le sucede a Reina.

Hay sufrimiento, hay explotación, hay soledad, hay dolor, hay hambre, hay desarraigo.

En "Teoría y conceptos asociados al estudio de las migraciones internacionales", Amparo Micolta León, al citar a Tizón García, apunta que entre los aspectos de la migración se halla el de la preparación para el viaje, para el desplazamiento, lo que conlleva no una salida inmediata, sino una toma de conciencia de lo que significa su vida en el espacio que desena o deben abandonar, por lo cual la inmediatez de la decisión tiene lugar. La idealización del lugar de destino puede tener fuerte incidencia en ello, lo cual lleva a o los migrantes a emprender el viaje. Es justo lo que lleva a Reina a convencer a Marlon para que ambos lleven a cabo tal viaje.

Por su parte, la novela de Junot Díaz plantea el conflicto interno del personaje, no solo en su historia y la de sus familiares como sujetos migrantes, sino en su proceso interior de derrota: un proceso de migración que lo va degradando o que al menos lo reduce, lo hace sentir como tal, ante los demás.

\section{(c) (i) (9) (2)}

La Revista Estudios es editada por la Universidad de Costa Rica y se distribuye bajo una Licencia Creative Commons Atribución-NoComercial-CompartirIgual 3.0 Costa Rica. Para más información envíe un mensaje a revistaestudios.eeg@ucr.ac.cr. 


\section{Especial: Profesores de Estudios Generales Investigan}

Óscar es un sujeto introvertido, enamoradizo, pero incapaz de lograr el amor de una mujer, pues es feo, gordo, contrahecho, y gusta de las mujeres hermosas, a las cuales no tiene acceso alguno. Todo ello lo va reduciendo, lo aísla aún más en su relación con el mundo, y lo lleva a vivir las historias de los cómics como forma de escape y de vida, como una manera de construirse a sí mismo como un super héroe dentro de su mundo de soledad, deseoso de ser aceptado por los demás.

Ambas novelas enfrentan a los personajes con sus dilemas diarios, sus procesos de crisis y de derrota.

Por tal motivo, la novela de Jorge Franco intercala la historia del desplazamiento que hacen Marlon y Reina en su tránsito de Nueva York hacia Estados Unidos, y el momento en que Marlon, después de perder a Reina en Nueva York y ubicarse laboralmente en un restaurante colombiano ubicado en la Gran Manzana, intenta por todos los medios posibles localizar a esta.

Marlon se ha extraviado cuando intentaba escapar de la policía, y al no hablar inglés y no conocer la ciudad, le es imposible reencontrarse con Reina. El tiempo pasa y transcurre más de un año, mientras se da cuenta luego de que esta nunca intentó localizarlo a él, pues solo lo lleva a Estados Unidos con una excusa falsa. Va en busca de su madre, a la que encuentra, y se desliga de Marlon, mientras este intenta encontrarla desesperadamente. Su amor por esta contrasta con el desamor que vive Óscar en su mundo, en su distancia con respecto a los demás.

El fukú se ensaña contra Óscar, como esa maldición que persigue a su familia desde el escapa de la tiranía de Trujillo. Óscar es la víctima que sufre todos los desplantes, rechazos que su familia ha llevado consigo por generaciones. Es una especie de portador de la fatalidad familiar, del sino de desgracia que lleva esta a través de generaciones.

\section{(c) (†) (-)}

La Revista Estudios es editada por la Universidad de Costa Rica y se distribuye bajo una Licencia Creative Commons Atribución-NoComercial-CompartirIgual 3.0 Costa Rica. Para más información envíe un mensaje a revistaestudios.eeg@ucr.ac.cr. 


\section{Especial: Profesores de Estudios Generales Investigan}

Con base en ello, es claro que también el factor asignado a la superstición es un claro índice de lo que para estos significa la maldición no solo de su familia, sino también de la Nación en general.

Busca en la escritura una forma de salida, de vencer sus complejos y convertirse en alguien, en ser reconocido y adquirir notoriedad.

Oscar luego conoce a Ana Obregón, y la amistad que siente por ella al principio se va convirtiendo en amor. Pero esta tiene un novio, Manny, verdadero delincuente y abusador. La maltrata y el pesar de Óscar es el de no poder hacer algo por ella. Desea librarla del tipo, pero no puede pues ella lo ama, según sus palabras.

No logra encontrar solución a su conflicto. Desea estar con Ana, pero la proximidad del violento novio de esta lo impide, incluso a pesar de los golpes que le propina a esta.

Vislumbra su vida en el momento en que decide matar al novio de Ana, lo cual no se llega a dar, pero sí carga con la idea de que ha de renunciar a sus sueños con tal de eliminar a I parásito de Manny. Su hermana se da cuenta y lo disuade de lo que ha de hacer.

Su entrada a la universidad es una repetición de los rechazos por su piel y aspecto, por su cabello y su forma de ser. No logra, al menos al principio, ser mirado de la forma en que lo desea por las universitarias, y termina por inscribirse en el grupo de nerds de la institución, los RU Gamers, lo cual lo confina más, pero le das un espacio de orgullo en lo que hace, y posiblemente de aceptación entre otros como él.

Óscar y su hermana se ven sujetos a la voluntad de una madre con la cual no encuentran cariño, y en la que ven más a una persona ajena que a una verdadera madre. No hay abrazos, no hay besos, no hay palabras de aliento para estos que

\section{(c) (i) (2) (2)}

La Revista Estudios es editada por la Universidad de Costa Rica y se distribuye bajo una Licencia Creative Commons Atribución-NoComercial-CompartirIgual 3.0 Costa Rica. Para más información envíe un mensaje a revistaestudios.eeg@ucr.ac.cr. 


\section{Especial: Profesores de Estudios Generales Investigan}

deben enfrentar un mundo difícil hacia afuera, pero también hacia adentro, hacia sus propios seres, en el intento de darle una razón a la existencia. La misma razón que intenta hallar Reina en su "escapatoria" de Colombia, y la razón que busca Marlon al huir con ella.

Por tal motivo, en Paraíso Travel ni siquiera el padre de Reina, que se queda en Colombia, tiene comunicación con esta la cual, a su vez, ha robado una fuerte cantidad de dinero al prometido de una de sus tías. Ello para poder pagar los pasajes de transporte, en una odisea sorprendente, hacia la nación del norte.

Marlon, en medio de su extravío, se da cuenta de lo que representa su viaje. Es un disparate, que pierde por completo su lógica. El motivo del viaje, Reina, se encuentra perdida, según él lo cree, cuando en verdad los demás personajes le indican que el perdido es él. Esto ya le brinda una idea de lo que representa su condición de migrante en un país desconocido

Pude haber muerto ese amanecer en que perdí mis pasos, no sólo porque la misma muerte me tocó el hombro sino porque lo deseé con rabia. Recordé y entendí las tantas veces que Reina decía: mejor matémonos, y que de tanto decirlo ya nadie le abría los ojos como al comienzo.

Mejor matémonos- decía iracunda ante cualquier contrariedad.

Yo temía no sólo por la vida de Reina sino por la de todos, por la mía, que yo cuidaba sin explicación, o tal vez por ese amor pesimista que siempre le he tenido a la vida. Amor que me duró hasta esa noche en que fui el más desesperado de todos los vivos, cuando por primera vez pensé: mejor muerto, peor vivo y sin Reina. Aunque fue precisamente el recuerdo de sus ideas extrañas él que me llevó a considerar que podía dar unos pasos más.

Supe que al correr comenzaba a perderla, que también me perdía yo en lo que dura un parpadeo. Mientras huía de los policías pensé en ella, en su boca iracunda después del grito: ¡no salgas, Marlon!

Pero mi rabia también contaba y salí sin sospechar que esa noche me iba a perder en el más grande y enredado de los laberintos, resignado a tener como último recuerdo de Reina su gesto bravo, llamándome como de niño me advertía mamá: ¡no salgas a la calle, Marlon Cruz!

\section{(ब) $(\Theta \odot$}

La Revista Estudios es editada por la Universidad de Costa Rica y se distribuye bajo una Licencia Creative Commons Atribución-NoComercial-CompartirIgual 3.0 Costa Rica. Para más información envíe un mensaje a 


\section{Especial: Profesores de Estudios Generales Investigan}

Le grité a Reina y salí. Nos gritamos el cansancio y el silencio que habíamos guardado desde que le dijimos sí al disparate de venir a buscar FUTURO A Nueva York (Franco, 2008: Pág. 9).

La crisis que enfrentan los personajes en ambas novelas les pone en evidencia la pequeñez de sus condiciones. Marlon se siente derrotado desde el inicio, lo mismo que Óscar.

Por ello, una serie de historias van enlazando la idea de la fatalidad señalada, a su vez, en la novela de Díaz: la de los abuelos, la de la madre, la de la hermana, la misma de Oscar, y todos aquellos que forman parte de su núcleo inmediato. La huída, el intento de escapatoria, física y psicológica, es lo que delimita la existencia de cada uno de ellos, y los define como sujetos signados por la fatalidad y la derrota.

Es por ello por lo cual Óscar se aísla del mundo y busca en los comics una salida desesperada a su infortunio: es sumamente obeso, ‘poco atractivo, solitario, taciturno, sin espacio de comunicación con el resto de la sociedad. Carece de empatía para con los demás. Es un perenne enamorado, pero no recibe reciprocidad por parte de las mujeres. Es un personaje, en definitiva, acaso simbólico de lo que significa una sociedad sin asidero, sin metas, sin reconocimiento. Desde tal perspectiva se distancia de Marlon, al cual la suerte con las mujeres parece favorecerlo, pero su autoestima, en un mundo ajeno, termina por minimizarlo.

Por su parte, la hermana de Óscar, Lola es también solitaria, carece de metas definidas, a diferencia de Óscar, el cual desea, por lo menos dentro de su soledad, convertirse en escritor, y lo va logrando, mientras que Lola emprende aventuras en las cuales termina por fracasar, como el viaje a otro país, por ejemplo, y regresa derrotada y con enorme desencanto. Esta se siente vacía, y va en busca de algo 


\section{Especial: Profesores de Estudios Generales Investigan}

que, en definitiva, no sabe a ciencia cierta qué es. No tiene grandes objetivos vitales. En este aspecto se manifiesta también su sino trágico, el peso de su familia en lo fatídico, la herencia generacional que los marca y los reduce.

A su vez, Belicia de León, madre de Óscar y Dolores, en su vida ha sufrido también el bulling por lo cual ha aprendido a luchar y a enfrentarse contra lo que venga, sin que eso implique haber alcanzado el triunfo. Su belleza ha sido cediendo con el tiempo, mientras el cáncer la alcanza en la edad madura y la va deteriorando lentamente.

Los tres, madre e hijos, se refugian en la fantasía como una forma de escapar de la realidad. Óscar y Dolores salen de Puerto Rico en busca de mejores condiciones, las cuales, como sujetos a un determinismo establecido, les impide claramente un mayor reconocimiento y una mejor forma de vida. La realidad, el entorno los reprime.

Óscar es el nerd, el escritor, que en la soledad encuentra un espacio para sí mismo, pero con la añoranza del reconocimiento, de la posibilidad de tener una pareja y de recibir un mayor respeto en el mundo en el cual vive. Búsqueda prácticamente infructuosa.

Con respecto a la novela de Jorge Franco, el mundo de Marlon y de Reina corresponde a un espacio de excesiva pobreza, carente de ideales. Si bien Marlon es estudiante de Filosofía, o aspira a estudiar esta, parece no estar seguro de sus propios estudios. La presencia de Reina se torna vital para él, por lo que está dispuesto a seguirla a ultranza. En palabras de los propios personajes, el entorno en el cual se desarrollan es un mierdero que no les da la oportunidad de metas inmediatas ni para el futuro

-Nos vamos los dos- dijo.

\section{(2) 100}

La Revista Estudios es editada por la Universidad de Costa Rica y se distribuye bajo una Licencia Creative Commons Atribución-NoComercial-CompartirIgual 3.0 Costa Rica. Para más información envíe un mensaje a 


\section{Especial: Profesores de Estudios Generales Investigan}

También habló de las oportunidades, de los dólares, de ganar bien, de vivir mejor, de salir de este pobre mierdero.

-Aquí no hemos hecho, ni estamos haciendo, ni vamos a hacer nada.

De tener por fin un sitio para los dos, de prosperar, y hasta de tener hijos, habló. Lo dijo con los ojos muy brillantes, y tan sinceros que le creí. Tan decididos que me asustaron (Franco, 2008, p. 10)

En ambas novelas, la crisis existente a lo interno en sus países los obliga a la salida, ya sea por miedo a la muerte, por amenazas, por búsquedas personales desesperadas...por un intento de una vida mejor, en definitiva.

Eso es lo que ocurre, precisamente, en la novela de Junot Díaz, la cual empieza durante la tiranía de Trujillo. Por lo menos, una serie de acontecimientos remiten a esta y, claro está, ya desde allí se habla del FUKU y el concepto de la maldición. Además, ello prefigura la historia de derrotas, persecuciones y tragedia que ha de acompañar a la familia de Óscar desde su abuelo en adelante.

La maldición que se cierne sobre sus ancestros, y que se extiende a sus descendientes, los acompaña incluso en su salida de República Dominicana. Por ello Óscar se ve como un inmigrante fracasado, lo mismo que su hermana, y aunque pueden regresar a su patria, la suerte sigue siendo la del desterrado, la del sujeto sin asidero.

El texto apunta al peso nefasto de Balaguer en el proceso de la diáspora. Es de nuevo una especie de persistencia de maldición que se cierne sobre el pueblo en general y se ensaña, por lo menos en la novela, con la familia de Óscar. Ni siquiera la caída de la tiranía les augura un futuro mejor por lo cual la migración interna y externa es lo que los caracteriza. Es el proceso de pérdida, no solo de lo material, sino incluso, y en gran medida, de la dignidad.

\section{(c) (i) (-)}

La Revista Estudios es editada por la Universidad de Costa Rica y se distribuye bajo una Licencia Creative Commons Atribución-NoComercial-CompartirIgual 3.0 Costa Rica. Para más información envíe un mensaje a 


\section{Especial: Profesores de Estudios Generales Investigan}

En verdad el proceso original de desplazamiento responde régimen de terror que se implanta en República Dominicana y que propicia la inevitable salida de aquellos que son asediados o reprimidos, o que no encuentran las condiciones adecuadas para continuar en la isla.

El embarazo de Belicia, que la lleva a perder al bebé, la pone en peligro ante esposa del hombre que la embaraza, apodado el Gánster, el cual le promete amor, pero sin que ello implique la ruptura con su mujer, que además es hermana de Trujillo. Esta, al saber lo que ocurre, conspira contra Belicia que, embarazada del gánster, y por lo que implica el nacimiento del hijo, envía a unos matones que la golpean y le provocan aborto. Queda muy maltrecha y su amante, ligado a Trujillo como mano derecha, no le ofrece ayuda ni protección en momento alguno. Belicia, aún muy joven, percibe lo que representa su situación y el conflicto con su madre, la cual le ha advertido del peligro al cual se exponía.

Ello es también factor fundamental dentro de lo que representa el sino trágico del clan familiar.

Las novelas anudan ese frenético deseo de escape de condiciones adversas, y ello reafirma la migración como búsqueda de una posibilidad de esperanza de mejoramiento.

En verdad están huyendo, al parecer, de condiciones sin futuro, lo cual los empuja a un proceso de migración en exceso inhumano. Migrar implica mejorar, de acuerdo con lo que en principio plantea Reina, en la novela combiana. No obstante, la llegada a la tierra prometida les revela la dureza de la inserción a un medio que les resulta adverso en gran medida. Los personajes de las dos novelas sufren esto.

Reina construye un mundo idílico para Marlon, pero el encuentro es más bien el de un caos, un infierno que desfigura, de golpe, los sueños de este. Ya el solo 


\section{Especial: Profesores de Estudios Generales Investigan}

proceso de llegada le resulta totalmente ingrato. Son explotados, asaltados, sufren calor, sufren hambre, duermen en condiciones deplorables, son vejados, les roban la mayor parte del dinero, son tratados como bestias más que como seres humanos. Es la marca que va dejando el tránsito de desplazamiento de esa migración que se convierte en un vaticinio de lo que han de hallar

La idea fue suya. Se lo reclamé cuando llegamos. Ya no nos quedaba dinero, no existía la dirección a donde teníamos que llegar y las cosas no habían salido como esperábamos. Habíamos aguantado y callado durante todo el trayecto. Casi no dormimos porque el sobresalto no nos dejaba, y en el día tampoco pudimos descansar y muchas veces dudé si alguna vez llegaríamos adonde Reina quería llegar (Franco, 2008, p. 11)

Marlon no niega la posibilidad de salir si ello implica una forma de mejoramiento, pero se siente sin lugar. De hecho, su fisonomía lo "descalifica" para ubicarse allá, mientras admite que los ojos claros de Reina, y su cabello bien la pueden establecer como una estadounidense más. Se siente ajeno a ese mundo, sin posibilidad de calzar en él.

Por ello, y a su vez, en La breve y maravillosa vida de Oscar Wao, la novela parece mezclar la fantasía de Óscar con acontecimientos de su entorno, por lo cual en ocasiones aparecen elementos y personajes de la ciencia ficción, a la cual este es aficionado de forma obsesiva. En el contexto de los personajes parece establecerse esta dimensión del desarrollo, que solo tiene espacio en la mente del joven.

El mundo de Óscar Wao, por su parte, es un mundo de ficción, pero en el cual aprende a sobrevivir mientras evade la durísima realidad en que le corresponde desarrollarse: gordo en exceso, muy enamorado, nada atractivo, víctima del "bulling", migra hacia su interioridad, mientras que con el tiempo lo ha de hacer espacialmente. A diferencia de él, Marlon migra espacialmente, aunque en su

\section{(c) (i) (2)}

La Revista Estudios es editada por la Universidad de Costa Rica y se distribuye bajo una Licencia Creative Commons Atribución-NoComercial-CompartirIgual 3.0 Costa Rica. Para más información envíe un mensaje a 
Especial: Profesores de Estudios Generales Investigan

búsqueda frenética de Reina, parece surgir una migración que implica un encuentro consigo mismo.

Con respecto a Óscar, sus abuelos y madre, sus tíos y tías, deben soportar las leyes del Estado, las cuales son establecidas por Trujillo o funciona a favor de este.

Es por ello que cabe resaltar que el apego desesperado a la vida, por parte de Belicia, pese a lo que vive, en medio de un mundo que la mira con admiración y recelo debido a su belleza sobresaliente, de la cual intenta sacar provecho, pero que de igual manera le pasa la factura, pues su existencia, en algún momento, y aquí deviene su aparente desamor para con sus hijos, es tan dura que no sucumbe ante el suicidio, sino que decide seguir luchando. Pierde la promesa del hombre al cual ama, ve destruidas sus posibilidades y luego, al quedar de nuevo embarazada de otro hombre, aprender a lidiar con el desencanto. Es por ello que es incapaz de demostrar amor por sus propios hijos, una palabra de cariño, un abrazo o una caricia. Es una mujer vacía, y ello le impide, a pesar de que lucha por vivir, un mayor apego para con el mundo. De hecho, una criatura legendaria en la isla, y los cuidados de La Inca, salvan a Belicia de la muerte, después de la brutal golpiza que la hermana de Trujillo ordena que le den.

Es por lo anterior por lo cual se van configurando las circunstancias que han de llevar a Óscar y a su hermana, y a muchos más, a emigrar de la isla. Es el exilio, la migración como formas para buscar dejar atrás el proceso de supervivencia y buscar, en adelante, una verdadera posibilidad de vida.

Por otro lado, en Paraíso Travel, Reina muestra fotografías ubicadas en la mentira a Marlon. Es la promesa de un mundo mejor, en el espacio de la prima, que vive allí. Luego Marlon se ha de dar cuenta de que Gloria no es la prima, que no vive en las condiciones que Reina le muestra en las fotos, que el mundo de ensueño

\section{(c) (i) (2)}

La Revista Estudios es editada por la Universidad de Costa Rica y se distribuye bajo una Licencia Creative Commons Atribución-NoComercial-CompartirIgual 3.0 Costa Rica. Para más información envíe un mensaje a revistaestudios.eeg@ucr.ac.cr. 


\section{Especial: Profesores de Estudios Generales Investigan}

no lo es en verdad. Es precisamente la mentira que encubre, en gran medida, el ensueño del migrante. Es el desencanto de Óscar, de Marlon, de Lola, de Belicia, de los migrantes.

La llegada, después de la dolorosa travesía de desplazamiento hasta el norte, se convierte en un golpe: es el encuentro con la pobreza, con el desempleo, con la soledad, con la desposesión. Es la idea del tugurio que golpea la desesperación de Marlon, despojado de todo, sin dinero, en conflicto, preocupado y sujeto apenas a lo que Reina le promete, pero de lo cual él duda. Es la búsqueda de Óscar, que no logra culminar.

Marlon, aun con la presencia de Reina, ya se encuentra perdido, tal como se lo enuncia a ella. La pregunta por el qué van a hacer pone de manifiesto su enajenación con respecto a lo que lo rodea. La carencia de papeles, de los cuales se han desprendido en el camino, por orden de quienes se definen como sus guías, para evitar conflictos en las fronteras y ser deportados, los sume en una des identificación plena. No son, parecen ya no existir en ese mundo extraño para el joven.

A Marlon se le construye el mundo como mentira. Reina construye la mentira y se la ofrece, sin dejarle la posibilidad abierta del cuestionamiento, que solo logra entender plenamente este cuando se encuentra sin ella, desposeído de la mentira, y de cara a la dura realidad de su condición de migrante, de sujeto ilegal en un país que, con el advenimiento de los policías, ha de comenzar a reprimirlo.

Es por lo anterior cuando, con la llegada de Reina y Marlon a Nueva York, y la huída desesperada de este para no ser capturado por los policías que le reclaman sus papeles, se pone en evidencia que Marlon continúa su proceso de escape, de su tierra primero, y de la tierra que lo "acoge", después. Pierde su arraigo, se encuentra extraviado, perdido. El paraíso prometido se convierte en su pesadilla.

\section{(c) (i) (2)}

La Revista Estudios es editada por la Universidad de Costa Rica y se distribuye bajo una Licencia Creative Commons Atribución-NoComercial-CompartirIgual 3.0 Costa Rica. Para más información envíe un mensaje a revistaestudios.eeg@ucr.ac.cr. 


\title{
Especial: Profesores de Estudios Generales Investigan
}

Fumar un cigarrillo por fuera del cuarto miserable donde estaban hospedados, lo pone de cara ante una realidad indeseada, lo cual lo empuja a huir

\begin{abstract}
Él habló y yo no le entendí. Señaló la patrulla que yo no había visto, o tal vez señaló a su compañero que hablaba por radio. Creó que balbuceé y también creo que él dijo algo que tampoco entendí pero que hizo que mis pies decidieran por mí. Y mientras él miro al otro lado para hablarle, yo eché a correr a grandes zancadas empujado por el pánico, atropellando a la gente pero sin caer; miré hacia atrás y los policías también corrían, no muy lejos, abriéndose pasos con sus silbatos y con sus armas desenfundadas pero todavía sin apuntar. Mis pies volaban y a mis pies frenaban los carros en cada calle que cruzaba. Veía sus luces como si corriera dentro de un carrusel. Los policías siguieron persiguiéndome pero el miedo me hizo más veloz (Franco, 2008, p. 14)
\end{abstract}

Por su parte, en la novela portorriqueña, se lleva a cabo la salida desesperada hacia la condición de migrante para poder "vivir", pues en ocasiones tal proceso de migración o escape no garantiza un mejoramiento. Si bien Óscar evoluciona como escritor, en el plano personal continúa su decadencia. Es una lucha contra el entorno, contra la no aceptación, contra el rechazo. Quizás logre un relativo éxito en el plano profesional, pero en el personal deambula permanentemente por la derrota.

Y es que la oscuridad del pasado obliga a los personajes a migrar, a escapar de condiciones que les son adversas, como le ocurre a Belicia al intentar escapar de un imposible, el Gánster, que en verdad es más un símbolo de la impunidad y del ejercicio brutal y salvaje del poder:

Dieciocho días después, todavía estaba pensando en él en el aeropuerto.

No tienes que irte, dijo La Inca, de repente, en el preciso momento que la muchacha se unía a la fila. Pero eras demasiado tarde.

Quiero irme.

\section{(c) (i) (-)}

La Revista Estudios es editada por la Universidad de Costa Rica y se distribuye bajo una Licencia Creative Commons Atribución-NoComercial-CompartirIgual 3.0 Costa Rica. Para más información envíe un mensaje a 


\section{Especial: Profesores de Estudios Generales Investigan}

Toda la vida había tratado de ser feliz, pero Santo Domingo....FOKIN SANTO DOMINGO la había frustrado a cada paso. No quiero volver a verlo nunca más.

No hables así.

No quiero volver a verlo nunca más (Díaz, 2010, p. 178)

Reiteramos, entonces, que la novela registra la historia de la familia de Óscar, antes y durante su proceso de emigración.

A su vez, en el texto colombiano, el manejo cronológico del tiempo, que va de la historia de ambos a la de Marlon en su presente, luego se acelera. Pasa un año, y la búsqueda continúa. Marlon se comunica telefónicamente con su familia, y se da cuenta de que Reina no lo hace con los suyos. Este logra encontrar trabajo, desde lo más bajo que se pueda concebir, al limpiar baños, pero se rehúsa a regresar hasta tanto no encuentre a su novia, la cual desaparece, aunque, como se ha señalado, el desaparecido es él. Sobrevive buscando a Reina, así como Óscar lo hace por medio de la escritura.

Sin embargo, Marlon se pierde no solo en el espacio que lo rodea, sino también en su propio conflicto. No logra resolver su relación con Reina con la cual viaja pero que luego lo deja, sin que él sea consciente de ello. El entorno le resulta ajeno, pero el conflicto lo lleva dentro de sí. Ha partido con Reina sin estar totalmente convencido. Ha viajado y sufrido, con el deseo latente del regreso. Cuando pierde a este (cuando él se pierde) no opta por el regreso, sino que insiste en su lucha por encontrarla. Curiosamente, cuando la encuentra a quien en verdad halla es a sí mismo, pues entiende el engaño de esta, opta por dejarla apenas la ha reencontrado y, sin que la novela lo mencione, quizás deja abierta la posibilidad del regreso con Milagros que al fin y al cabo es el verdadero milagro que le ha ocurrido en cuanto a la posibilidad de rehacer su vida afectivamente.

El viaje y la llegada no son los únicos que le representan un episodio marcado por un augurio negativo. Ya desde antes de partir, Carlitos, uno de sus amigos, le

La Revista Estudios es editada por la Universidad de Costa Rica y se distribuye bajo una Licencia Creative Commons Atribución-NoComercial-CompartirIgual 3.0 Costa Rica. Para más información envíe un mensaje a 


\section{Especial: Profesores de Estudios Generales Investigan}

advierte en torno a la vacuidad de este viaje, pues si la pobreza los marca en el país, no garantiza que logren superarla en otro lugar, en donde posiblemente van a sufrir peor, y van a ser denigrados

Me lo había dicho Carlitos, que se mosqueaba mucho siempre que se tocaba este tema. Él nunca estuvo de acuerdo con nuestro viaje. Me insistió hasta el cansancio: te vas a comer toda la mierda que no te has comido nunca.

-Pero mierda gringa- me dijo Reina, después (Franco, 2008: pág. 22)

Luego, cuando ya en los Estados Unidos es rescatado por Patricia, la esposa de Pastor, el dueño del restaurante al cual llega casualmente Marlon este le pone en evidencia, al mirarlo cansado, hambriento, perdido, solitario, sin asidero alguno, que mejor le hubiera ido quedándose en Colombia. Es la forma de evidenciarle lo que representa llegar a un lugar que no lo recibe de forma adecuada, donde lo espera una pobreza mayor. Es el resultado de una migración que no ofrece salida alguna a su situación de carencia, sino que la empeora. El desarraigo de la patria lo pone en situación crítica y angustiante. Está perdido en un espacio que, de golpe, no lo acepta. Es la Otredad en ese mundo, aun cuando tal espacio también lo sea para él.

También desarraigado, y marcado por la Otredad, Óscar, cuyo verdadero apellido es De León, adquiere el mote de Wao, debido a una broma, o una comparación caricaturesca que le hace Max Sánchez, un anterior novio de Lola, al compararlo con Oscar Wilde, y pasa a denominarlo Óscar Wao:

Para Halloween, cometió el error de vestirse de Doctor Who y encima estaba de lo más orgulloso de su disfraz. Cuando lo vi en Easton Street, con otros dos payasos de la sección de escritores, no podía creer cuánto se parecía a Óscar Wilde, el homo gordo, y se lo dije. Te ves igualito a él, lo que fue una desgracia para Óscar, porque entonces Melvin preguntó, ¿Óscar Wao? ¿Quién es Óscar Wao? Y ahí mismo fue: todos comenzamos

\section{(C) $(00$}

La Revista Estudios es editada por la Universidad de Costa Rica y se distribuye bajo una Licencia Creative Commons Atribución-NoComercial-CompartirIgual 3.0 Costa Rica. Para más información envíe un mensaje a 


\section{Especial: Profesores de Estudios Generales Investigan}

a llamarlo así. Hey, Wao, ¿qué tú hace? Wao, ¿vas a quitar los pies de mi silla?

¿Y el colmo de la tragedia? Después de un par de semanas, el tipo comenzó a contestar (Diaz, 2010, pp. 194-195)

Su llegada como escritor, su conversión a ello es la forma en que la vida le resulta soportable. Escribir, y hacerlo desde la ciencia ficción, se convierte en su vía de escape, e incluso llama la atención, no solo para él, sino para quienes se mueven en su derredor, que su aspiración fundamental es convertirse en el próximo Tolkien dominicano. Lo desea, se prepara para ello, y se convierte en un nerd, un conocedor, una autoridad de lo que significan los cómics y este tipo de hacer literario que efectivamente lo van confirmando como escritor.

Cuando estudia, comparte cuarto con uno de sus compañeros, Yunior, el cual intenta protegerlo e incorporarlo al mundo que le resulta ajeno, distante. Si bien logra dar algunos pasos al respecto, termina por ensimismarse y de nuevo se aísla, al considerarse rechazado. Sigue sin lograr tener una relación, a pesar de que durante su niñez tiene dos novias, de las cuales la separación es abrupta. Un noviazgo de inocencia, más nominal, que no implica contacto alguno. De hecho, Wao llega al final de su vida con una sola relación sexual, que se da poco antes de morir, y que de alguna manera define precisamente la llegada de su muerte. Tal relación se define como el éxito vital de su vida. Era quizás su máxima aspiración en medio de un mundo en el cual no tenía lugar alguno.

Las mujeres que conoce a lo largo de su vida pasan por su existencia de forma efímera, distante incluso. Se enamora de ellas y no logra materializar con estas su necesidad de afecto. De hecho, Ibón Pimentel, la prostituta a la cual conoce al final de su vida, se convierte en la única mujer que le brinda el afecto que deseaba, que le arrebata la virginidad que tanto pesaba a Óscar, pero que también define el final de su amante, pues la relación con su novio establece la

\section{(c) (i) (9)}

La Revista Estudios es editada por la Universidad de Costa Rica y se distribuye bajo una Licencia Creative Commons Atribución-NoComercial-CompartirIgual 3.0 Costa Rica. Para más información envíe un mensaje a 


\section{Especial: Profesores de Estudios Generales Investigan}

derrota final del escritor, el cual, irónicamente, encuentra su muerte de una forma satisfactoria.

La muerte de Óscar de alguna forma parece definir el final de la maldición, sin que ello implique el sino trágico de la madre y su hermana. Es una especie de gradación de él, y de degradación de su hermana y madre.

En relación con esto, la estadía de Marlon en Nueva York, y el cierre de la novela, constituyen un proceso de gradación. Marlon cambia, finalmente, en su percepción con respecto a Reina. Esta pierde ese espacio simbólico, como su nombre lo dice, ante el novio abandonado. Reina se despoja de su máscara ante este, y evidencia la mentira que le recubre. Se degrada ante su ahora ex novio. Marlon, por su parte, madura, pone de manifiesto un cambio positivo. Su encuentro último con Reina es el rompimiento total con esta, con la falsedad de esta, que incluso tiene un hijo que trata de esconder a aquel, y que prefigura que quizás le pertenezca a Marlon, sin evidenciarlo plenamente.

Si bien ambos construyen su historia de amor en Colombia, y es ella precisamente quien seduce a Marlon, muy jóvenes ambos, el encuentro los pone de cara al sueño de la joven, no de Marlon: el viaje a Estados Unidos, donde ella ya ha estado antes, y que define la separación de sus padres. La madre se queda en el país del norte, mientras el padre regresa, derrotado y con su familia disgregada.

El discurso de Reina es el de que hay que salir, pues ya no hay oportunidades en Colombia, debido a la profunda crisis que golpea a la nación. Marlon no logra ingresar a la universidad pública, lo cual lo deja en un estado ambiguo: no logra conseguir trabajo, y no puede estudiar pues aún debido a las condiciones adversas. La adversidad del país mueve a Reina a intentar convencer a Marlon para buscar "un futuro" en otro lugar 


\section{Especial: Profesores de Estudios Generales Investigan}

Ya tenía en la cabeza una idea y también un país, y recuerdo también mi desengaño porque pensé que no tendría Reina para rato; ella estaba en su último año de colegio y sus planes eran estudiar una carrera "lejos de esta mierda".

-En los Estados Unidos- me dijo segura.

Yo llevaba año y medio tratando de entrar a la universidad, a la pública porque para las otras no había plata ni cupo ni rosca. Pero las públicas cuando no estaban en huelga estaban en bancarrota o tenía uno que ser el recomendado de un político, o el superdotado o en afortunado entre miles para ingresar. Yo no cumplía ninguno de esos requisitos y mi única suerte hasta entonces, grande además, había sido que Reina se fijara en mí.

- ¿Sí ves? -Me decía ella-.Aquí no se puede hacer nada así uno quiera. Ahí te van a dejar haciendo fila hasta que les dé la gana de recibirte.

Yo no tenía nada para alegar. Colombia lo va dejando a uno sin argumentos. Por eso me quedé callado y porque tampoco podía considerar alguna opción por fuera del país. Si no me alcanzaban los pesos, menos iba tener para dólares. Tenía que darle la razón a Reina, y seguir haciendo fila hasta que les diera la gana de recibirme...(Franco, 2008, p. 38)

Es así como finalmente, en secreto, deciden la salida del país para emprender el viaje, a pesar de que se les niega la visa, lo cual está presupuestado en la visión de Reina, la cual, a su vez, ve en ello la posibilidad para que otros ejerzan un negocio clandestino, por medio de agencias viajeras fantasmas. Un elemento más en la línea de corrupción imperante. Ante ello decide irse y pagar una cantidad millonaria al lado de Marlon, para lo cual roban a una tía de esta y al prometido de la misma. Es la desesperación por la salida a como haya lugar.

En la novela de Junot Díaz, la represión de Trujillo crea un régimen de terror que obligan a huir a los que pueden hacerlo y a callar a aquellos que, sometidos por el poder del tirano, no pueden enfrentarse a este y deben permanecer subyugados

...sería difícil exagerar el poder que ejercía Trujillo sobre el pueblo dominicano y la sombra de miedo que cubría la región. El Homeboy dominaba Santo Domingo como si fuera su Mondor privado; no sólo encerró el país bien lejos del resto del mundo y lo aisló detrás de la Cortina de Plátano, sino que actuó como si se tratara de su propia plantación, como si él fuera el dueño de todo y de todos, matando a quien quisiera matar, a 


\section{Especial: Profesores de Estudios Generales Investigan}

hijos, hermanos, padres, madres. Les arrancaba las mujeres a sus maridos la misma noche de bodas y después se jactaba en público sobre "la gran luna de miel" que había tenido la noche antes. Su Ojo estaba en todas partes; tenía una Policía Secreta que dejaba chiquita a la Stasi y vigilaba a todo el mundo, incluso a los que vivían en los Estados Unidos; tenía un aparato de seguridad tan ridículamente voraz que si decías algo malo sobre El Jefe a las 8:40 de la mañana, antes de que el reloj diera las diez, ya estabas en la Cuarenta con una pica en el culo. (¿Quién dice que nosotros los tercermundistas somos incompetentes?) No era sólo del Señor Viernes Trece que uno se tenía que cuidar, sino de la Nación Chivata entera que había ayudado a crear porque, como todos los Señores Oscuros dignos de su Sombra, tenía la devoción de su pueblo. Se creía que, en algún momento, entre el cuarenta y dos y el ochenta y siete por ciento de la población dominicana estaba en la nómina de Policía Secreta. Tus propios fokin vecinos podían acabar contigo simplemente porque tuvieras algo que quisieran o porque te les adelantaste en la fila del colmado. Cantidad de gente se jodió de esa manera, traicionada por aquellos a los que consideraban sus panas, por miembros de sus propias familias, por tonterías que se le iban a cualquiera. Un buen día eras un ciudadano respetuoso de la ley, machacando maní en tu galería, y al día siguiente estabas en La Cuarenta, donde te machacaban los güebos. ¡La mierda era tan extrema que mucha gente creía de verdad que Trujillo tenía poderes sobrenaturales! Se rumoraba que no dormía, que no sudaba, que podía ver, oler, sentir sucesos que se producían a cientos de millas, que el fukú más terrible de la isla lo protegía (Díaz, 2010, pp: 238-240)

En ambos textos la salida es difícil, es caótica, y marca el devenir de los personajes. Por ejemplo, en Paraíso Travel, cuando finalmente se deciden y emprenden la odisea, encuentran de paso un verdadero tormento.

A pesar de las vicisitudes que deben afrontar y de los riesgos inminentes del camino, que los pone en peligro de muerte incluso, llegan a los Estados Unidos y se encuentran de cerca (fundamentalmente él) la desesperanza, la persecución, el hambre, el rechazo, la sensación profunda de abandono y de nuevo el miedo a la muerte, más palpable, más fuerte, debido a lo que representa esta lejos de la patria, en un lugar desconocido, y sin medios para lograr salir adelante.

\section{(c) (i) (2)}

La Revista Estudios es editada por la Universidad de Costa Rica y se distribuye bajo una Licencia Creative Commons Atribución-NoComercial-CompartirIgual 3.0 Costa Rica. Para más información envíe un mensaje a 


\section{Especial: Profesores de Estudios Generales Investigan}

Su encuentro con lo desconocido representa la dureza de la migración y el desenmascaramiento de lo que significa un sueño que no se materializa y que lo reduce por completo. Es el encuentro con el terror, con la impotencia de enfrentar un mundo desconocido. Todo allí es igual, tal como él lo define, pero de igual forma le resulta ajeno, atemorizante. De nuevo, es el concepto de una Otredad que lo amenaza. $\mathrm{Y}$ no tiene posibilidad de evasión a no ser la única que encuentra: correr de forma desesperada en medio de un entorno que lo extravía aún más. Su llegada al restaurante de Pastor y Patricia, si bien le representa una salida inmediata, también simboliza su caída, su descenso máximo

Que ella, entonces, siguió caminado despacio conmigo hasta el restaurante. Allí nos detuvimos y Patricia taconeó un par de veces sobre una puerta de hierro a ras de la acera. La puerta se abrió al instante y yo sólo vi una escalera de metal que bajaba a un sótano. Eso había sido parte de su trato con don Pastor: que no lo vean los clientes, que no se arrime por acá, que no salga del cuartico, que entre por el depósito, que se vaya lo más pronto posible.

-Baja- me dijo Patricia.

Me ayudó para que no perdiera el equilibrio, casi empujándome pero mermando mi miedo con palabras amables: que tranquilo mijo, que ahí va a estar mejor, que siguiera tranquilo. Yo bajé muy despacio, viendo cómo la acera llegaba a mi cuello, pensando lo que habrían dicho mis amigos si me hubieran visto: miren a Marlo cómo se lo está tragando la tierra (Franco, 2008, p. 55)

El proceso de asimilación es complejo para el migrante, y en ambas novelas las dificultades que enfrentan los personajes principales ponen de manifiesto la dureza de lo que representa la adaptación y readaptación.

Los sueños se convierten, en ocasiones, en premonición que dan cuenta de los nuevos eventos que han de caer sobre la familia de Óscar, como cuando Socorro, su abuela sueña la caída de Abelard (abuelo de Óscar) y de Jacqueline, su hija.

\section{(ब) $\odot \odot \odot$}

La Revista Estudios es editada por la Universidad de Costa Rica y se distribuye bajo una Licencia Creative Commons Atribución-NoComercial-CompartirIgual 3.0 Costa Rica. Para más información envíe un mensaje a revistaestudios.eeg@ucr.ac.cr. 
Especial: Profesores de Estudios Generales Investigan

Por lo tanto, Abelard es "condenado" a pesar de ser inocente, es encarcelado y torturado, como forma de aleccionar a quienes son contrarios, amenazantes o sospechosos para el régimen de Trujillo:

Antes de que Abelard supiera lo que pasaba, lo metieron en una celda común que apestaba a sudor de malaria y diarrea y estaba repleta de representantes impropios de lo que Broca pudo haber llamado la "clase criminal". Entonces los guardias le informaron a los otros presos que Abelard era un homosexual y un comunista-¡Eso es mentira!, protestó Abelard-, pero ¿quién le iba a hacer caso a un comunista maricón? En las dos horas siguientes lo acosaron de linda manera y lo despojaron de casi toda la ropa. Un cibaeño corpulento le exigió hasta los calzoncillos y cuando se los dio, el hombre se los puso por encima de los pantalones. Son muy cómodos, anunció a sus amigos. Obligaron a Abelard a agacharse, desnudo, cerca de los cubos de mierda; si intentaba arrastrarse a las zonas secas, los otros presos le gritaban: Quédate ahí con la mierda, maricón. Y así fue que tuvo que dormir, en medio de la orina, las heces y las moscas (Díaz, 2010, p. 253)

En Paraíso Travel, a su vez, los días se convierten en frustración. El viaje, infernal, da lugar a un nuevo espacio de desconsuelo y de sufrimiento. Si bien es acogido a de la mejor forma por parte de doña Patricia sigue guardando la idea de un mundo hostil, agreste para el migrante, lo cual se vuelve espeluznante cuando se mira en el espejo y descubre su rostro y su cuerpo deformados por el miedo, el hambre la desesperación

De haberme visto antes no hubiera entrado, o sin tan sólo hubiera sabido lo que me iba a encontrar en el espejo, que era pequeño como todo lo del baño, pero suficientemente grande para ver lo que horrorizaba a los otros, y lo que en ese instante también me estremeció. Frente a mí estaba la mejor prueba para alegar lo que siempre he dicho. Ahí estaba el que alguna vez no fui, pero que comenzaba a serlo a partir de esa tarde, así fuéramos distintos, porque nunca antes ni después vi a alguien tan distinto a mí en el mismo reflejo. Que si no fuera porque los dos movimos la cabeza sincronizadamente y nos tocamos la cara para reconocernos, o porque a los dos se nos notó el pánico, hubiera creído que alguien detrás del vidrio jugaba conmigo. Lo hubiera jurado si no fuera porque también lo vi y lo escuché nombrarla. Reina, dijimos al tiempo.

\section{(c) (i) (-)}

La Revista Estudios es editada por la Universidad de Costa Rica y se distribuye bajo una Licencia Creative Commons Atribución-NoComercial-CompartirIgual 3.0 Costa Rica. Para más información envíe un mensaje a revistaestudios.eeg@ucr.ac.cr. 


\section{Especial: Profesores de Estudios Generales Investigan}

Cuando empecé a quitarme la ropa mi di cuenta de que me había cagado en los pantalones. Estaba untado de mierda de la cintura para abajo. Pero la verdadera mierda vendría después, cuando comencé a despertar bajo la ducha. Poco a poco volví a ver toda la película. El repaso horroroso de todo lo que me llevó hasta allí, o por lo menos, hasta el punto que recordaba. . Con más miedo que cuando sucedieron las cosas viví cada momento, segundo a segundo, como dicen que les sucede a los que van a morir (Franco, 2008, p. 56)

Por todo ello, por lo menos al principio y hasta la mitad de la novela, Marlon es incapaz de desligarse de su sensación pesimista. Se siente perdido, pese a que su situación va mejorando, pero su verdadero interés que es el de encontrar a Reina, continúa sujeto a la nada, a la incapacidad de encontrarla. No añora su patria, pero no logra adaptarse por completo a un mundo que le resulta lejano, pese a vivir en él.

Marlon parece deambular identitariamente, no porque pierda su identidad, sino porque pasa por un proceso de conflicto existencial que lo golpea. Ante los demás, no es este quien busca a una novia perdida. En verdad leen la certeza de que es Marlon quien se halla perdido, y que se niega a aceptar el hecho de que esta nada hace por encontrarlo. Quizás Óscar atraviesa un proceso de búsqueda más complejo que este, pues su verdadero fin es el sí mismo, desde el inicio de su vida, y hacia ello enfoca sus esfuerzos.

Marlon vive una pesadilla. Se niega a salir de esta, se afirma en la expectativa de encontrar a quien no dese, en definitiva, encontrarse con él, pues su motivo principal para llegar a los Estados Unidos no es la permanencia con este. Es el reencuentro con la madre, alcoholizada, solitaria, abandonada y perdida en ese mundo que nada le ofrece como migrante.

Marlon no tiene una pesadilla sino que vive esta de forma permanente, lo cual lo asusta y lo reduce. Su sueño se desmorona, si es que alguna vez lo tuvo, y se ve inserto en la pesadilla de un mundo agreste. Lo que en principio representó la

\section{(C) $(\Theta \odot$}

La Revista Estudios es editada por la Universidad de Costa Rica y se distribuye bajo una Licencia Creative Commons Atribución-NoComercial-CompartirIgual 3.0 Costa Rica. Para más información envíe un mensaje a revistaestudios.eeg@ucr.ac.cr. 


\section{Especial: Profesores de Estudios Generales Investigan}

búsqueda de mejores condiciones en medio de la pobreza, termina por convertirse en desencanto y extravío. De tal forma lo vive Marlon como sujeto simbólico del migrante.

Es claro que la llegada a Nueva York implica un cambio radical en la existencia de Marlon y en su percepción del mundo. Es un encuentro con un universo desconocido, agreste incluso, monstruoso en tanto ciudad que "traga" o devora al sujeto. $Y$ del consejo de Giovanni, su amigo en Nueva York es el de la necesidad de enfrentarse a esa bestia enorme, inhumana y domarla, vencerla. Es la única forma de sobrevivir en el espacio que se le abre ante los ojos.

También en la novela de Díaz, la necesidad de cambios radicales golpean el devenir de los personajes. Las manifestaciones de represión traen el olvido, el deseo de este como una forma de evasión y escapa ante la represión de la cual son objeto, tal como le ocurre a Belicia, la madre de Óscar:

De hecho, a mi entender, con excepción de unos momentos clave, no creo que Beli volviera a pensar de nuevo en esa vida. Se entregó a la amnesia que es tan común en las islas, cinco partes negación, cinco partes alucinación negativa. Se entregó a la energía de las Antillas. Y con ella se forjó de nuevo (Díaz, 2010, p. 272).

Óscar posee una visión derrotista de su propia vida. Ante los demás establece una separación que lo minusvalora en relación con estos: no tiene relaciones de amistad, carece de novia a pesar de su deseo permanente de contar con una, es un sujeto que construye su existencia en términos de soledad, es poco agraciado físicamente como lo hemos citado anteriormente; es un sujeto distante, ensimismado, un nerd mirado de forma denigrante por parte de los demás, e incluso de sí mismo, y es por ello por lo que se refugia en su espacio vital y se "divorcia" del exterior.

En algún momento es incorporado a la academia como docente, lo cual le representa una posibilidad de ganancias económicas, pero no necesariamente de

La Revista Estudios es editada por la Universidad de Costa Rica y se distribuye bajo una Licencia Creative Commons Atribución-NoComercial-CompartirIgual 3.0 Costa Rica. Para más información envíe un mensaje a revistaestudios.eeg@ucr.ac.cr. 


\section{Especial: Profesores de Estudios Generales Investigan}

placer, pues ello significa en cierta manera hacerse evid3ente ante los otros, que representa la Otredad que lo agobia. Es su lucha contra el mundo de los dominicanos, pero también contra los de Estados Unidos cuando está en esta Nación.

Es por ello que el rumbo existencial de Óscar parece marcado por la fatalidad, y de tal manera él lo entiende, de su familia. Sus abuelos, su madre, sus tías, su hermana quedan a merced del fukú (fuck you), equivalente al mal de ojo que va persiguiendo generaciones de su clan familiar

A la vista, Óscar simplemente parecía cansado, ni más alto ni más gordo, sólo la piel bajo sus ojos, inflamados por años de callada desesperación, había cambiado. Por dentro, habitaba en un mundo de dolor. Veía flashes negros ante los ojos. Se veía a sí mismo caer por el aire. Sabía en lo que se estaba convirtiendo. Se estaba transformando en la peor clase de ser humano del planeta: un nerdote amargado y viejo. Se veía en el Game Room, escogiendo miniaturas el resto de su vida. No quería ese futuro, pero no veía cómo evitarlo, no sabía cómo salir de él. Fukú (Díaz, 2010: pág. 282)

De otra parte, la visión pesimista de Reina, en Paraíso Travel, cuando permanece en Colombia con Marlon, es la de un país asesino. El sueño es el de viajar a Estados Unidos, mientras construye el ideal de una Nación que en verdad es más imaginario que realidad. El país agobia, cansa, resigna y envilece, es lo que concibe esta con respecto a su propio país. Esa idea la transmite a su novio, que no logra entender lo que a Reina la obsesiona. Son percepciones diferentes en cada uno, lo cual, con el tiempo los ha de separar, sin que el propio Marlon logra dar ese paso sino hasta el final del texto, como una forma de salida y de construcción y reafirmación de sí mismo, y no a partir de lo que su novia defina.

Reina en algún momento atenta contra su propia vida, por cuanto no puede soportar la idea de no conseguir la visa. El hastío que siente es tal que prefiere 


\section{Especial: Profesores de Estudios Generales Investigan}

optar por la muerte antes que soportar la idea de quedarse de forma permanente en Colombia. Esto por cuanto, de forma reiterada, se encuentra en un país signado por la miseria, el desempleo, la pobreza, y esto los lleva, en general, a buscar una salida, aun cuando se encuentren con el rechazo en otro país. Es el dolor que los embarga, pero la necesidad de procurarse un empleo y una ganancia que les permita sostener a los suyos los lleva a esta decisión.

La idea que se tiene de los propios linda de forma negativa con la del país de origen. Reina exhorta a Marlon a tomar una decisión pues, como se lo consigna, solo en un país que irrespete a los suyos son capaces incluso de prohibirle la posibilidad de estudiar, como le ocurre a este. Ella concibe a Colombia como un país de brutos, por lo cual lo mejor es la salida, la migración como forma de buscar mejores horizontes. El apego a esta es lo que lo sostiene como migrante e indocumentado, pues se niega a regresar sin antes encontrarla, pues la sabe en algún lugar de Manhattan. La obsesión por esta es lo que lo encadena a una vida de pobreza y de alteridad.

Es por ello por lo cual cabe resaltar de nuevo la emergencia de los sueños como un símbolo, lo mismo que los ojos de Reina. El hecho de que esta posea ojos de distinto color, uno respecto del otro, deviene signo, pues es la ambigüedad de su condición, de ser colombiana y no desear serlo, de ser estadounidense, afincarse allí, sin lograr ser aceptada. Es la "rareza", la "extrañeza" lo que la caracteriza.

Por ello, el sueño de Marlon, cuando le cuenta a esta que ella deseaba matarse, pero que también él en el sueño defecaba peces anaranjados, lleva a esta a señalar que quizás significa que no todo lo que uno lleva adentro es mierda, es decir, no todo es negativa en la óptica de la joven. Es entonces cuando Marlon se da cuenta de que en verdad ese prisma, esa forma de ver el mundo e interpretarlo es lo que lo hace seguir a Reina más que la dualidad de sus ojos, la diferencia en el color de estos.

\section{(a) $(\triangle \Theta$}

La Revista Estudios es editada por la Universidad de Costa Rica y se distribuye bajo una Licencia Creative Commons Atribución-NoComercial-CompartirIgual 3.0 Costa Rica. Para más información envíe un mensaje a 


\section{Especial: Profesores de Estudios Generales Investigan}

La llegada a los Estados Unidos, y la adquisición de un trabajo, días después, se convierte también en un símbolo de lo que representa la llegada a esta Nación para el migrante, pues la puerta de entrada, reflexiona Marlon, es la de trabajar en los baños, limpiar la mierda de los demás, como forma de sentirse finalmente asimilado, lo cual jamás pasa por su mente en su propio país, en tanto significa una labor de desprestigio

-El último que llegue lava los baños.

No era una apuesta de niños sino una de las leyes de inmigración. Y como toda ley que se respete, no es para todo el mundo sino para el que tenga la mala suerte de caerle. Yo fui uno de esos. . No tuve siquiera el derecho de considerarla como arte de mi adversidad, sino, por el contrario, me tocó aceptarla como un privilegio. Hasta me felicitaron por haber conseguido trabajo.

-Eso merece una celebración -alcanzó a decir Giovanni Fonseca (Franco, 2008, p. 97)

Mientras, en La breve y maravillosa vida de Óscar Wao, este hace un viaje simbólico, pues va por la vida en busca del amor, así como el pueblo va en busca de mejores condiciones. Su migración física es también una migración interna que, sin embargo, no le permite evadirse de sus vacíos y carencias. La búsqueda de su familia termina por resumirse en la que hace Óscar, no solo de sí mismo como sujeto en su interioridad, sino también en la desesperada búsqueda de mejores condiciones en su entorno hostil.

Es por ello que su muerte le representa, paradójicamente, un triunfo, pues su encuentro sexual con Ibón, la pérdida de su virginidad con la prostituta, le representa un logro, quizás su mayor éxito, a la par de la atracción que se construye entre ambos, y que trae las consecuencias funestas que le cuestan la vida: Los celos del novio de ésta $Y$, por lo tanto, el ajusticiamiento de Óscar, pese

\section{(c) (i) (-)}

La Revista Estudios es editada por la Universidad de Costa Rica y se distribuye bajo una Licencia Creative Commons Atribución-NoComercial-CompartirIgual 3.0 Costa Rica. Para más información envíe un mensaje a 
Especial: Profesores de Estudios Generales Investigan

a las advertencias de éste, y de la propia "prometida" que Óscar se ha construido y que el texto parece ratificar.

La muerte de Óscar pone en evidencia el desarraigo, la decadencia, el fracaso que simboliza su familia, extendido a la población de República Dominicana. La enfermedad de la madre se agudiza, y vive diez meses más. Es enterrada junto al hijo, mientras Lola parece caer por completo, derrotada, y se resiste a volver a su país, pues encuentra en este el peor de las posibilidades; es una Nación en crisis, sin salida, y acosado aún por fantasmas, por lo cual migrar por completo es lo mejor:

Lola juró que nunca volvería a ese país tan terrible. En una de nuestras últimas noches de novios, dijo, Diez millones de trujillos, eso es todo lo que somos (Díaz, 2010: pág. 333).

La represión, el concepto de abatimiento está incorporado en el colectivo, simbolizado por Lola, la cual emigra a Estados Unidos y rompe sus lazos con el pasado.

Y como forma, a su vez, de rompimiento, durante su proceso, en el texto colombiano Marlon adquiere la noción de que parece despersonalizarse, ya sea porque lo asuma de esa forma o porque se le lea e interprete como un no sujeto, como una no persona. Se siente denigrado, pero es incapaz de oponerse radicalmente a lo que se le va signando. Dormir en una bodega, darse cuenta de que se ha defecado, soportar hambre y cansancio, ir cambiando su apariencia en muy poco tiempo en desmedro de lo que ha sido siempre, hallarse desposeído, sin dinero, sin hogar, sin cobijo alguno, y después de ser perseguido, entre otros aspectos, le da la sensación de no ser el mismo, sino de quedar sujeto a una condición de infrahumano. Es el migrante que no logra asimilarse, aun cuando después lo vaya logrando poco a poco.

\section{(C) $(\Theta \odot$}

La Revista Estudios es editada por la Universidad de Costa Rica y se distribuye bajo una Licencia Creative Commons Atribución-NoComercial-CompartirIgual 3.0 Costa Rica. Para más información envíe un mensaje a 


\section{Especial: Profesores de Estudios Generales Investigan}

La metáfora del excremento se traslada a la sensación misma del ser que define Marlon. Debe trabajar en ello, labor que considera indigna, después de viajar miles de kilómetros, en las peores condiciones, para terminar en un lugar en donde su oficio se reduce a limpiar baños, en medio de la suciedad, los orines y el vómito

Lo primero que consideré fue si valía la pena quedarme en este país no sólo a comer mierda, sino también a limpiarla. Y ajena, para colmo de males. Pensé si valdría la pena hacerlo por Reina. $Y$ como siempre que lo pensaba, la respuesta era la misma: vale la pena limpiar la mierda, comérsela y santificarla. Porque también en ese instante, al igual que en los días anteriores, me imaginé de vuelta, otra vez en mi país, en Medellín, y en mi casa, en mi cuarto con mis cosas, mis amigos y la comodidad de vivir con papá y con mamá. Me imaginé allí sentado, rodeado de todo y sin ella. Entonces me vi incompleto, sin un brazo, con pierna y media y medio ciego, como si hubiera pisado una mina de las que se cosechan en nuestros campos; me vi de mal genio y hasta calvo, y triste, tan triste como hoy, recordando lo que sentí cuando preferí la mierda al regreso.

-Entonces, ¿cuándo puedo empezar?- le pregunté a Patricia, y ella con una sonrisa generosa, como si el trabajo de verdad hubiera sido un regalo, me dijo:

-Hoy mismo, mijo, qué estás esperando (Franco, 2008, p. 100)

$Y$ es que en verdad se puede describir el texto como una historia de amor fallido, pero obsesivo, que le impide a Marlon, aun con la separación o la pérdida de Reina, regresar a Colombia. Su objetivo primordial es hallar a esta, y después establecerse. Pero el paso del tiempo también vas prefigurando un cambio en este, aun cuando no sea tan evidente. Ello se palapa en el encuentro cada vez más cercano con Milagros, pues aun cuando renuncia a esta, queda la posibilidad, al parecer, de un regreso cuando rompe finalmente con Reina en su encuentro final.

Durante su estadía allí, Marlon termina por perfilar su destino al hecho de que si no posee dinero, nada es. Es precisamente la posesión de esta la garantía fundamental de su identidad. Acaso se ve inmerso en él la idea, ya configurada en el imaginario, de que solo se es en tanto se posea, y la apariencia está por encima

La Revista Estudios es editada por la Universidad de Costa Rica y se distribuye bajo una Licencia Creative Commons Atribución-NoComercial-CompartirIgual 3.0 Costa Rica. Para más información envíe un mensaje a 


\section{Especial: Profesores de Estudios Generales Investigan}

del ser. Es la esencia de lugar, del país. Es el advenimiento del vacío como sujeto, y la carencia lo que lo lleva a sentirse en ocasiones menos que los demás.

La llegada a la tierra prometida se convierte en posibilidad para algunos, y en engaño para otros. Marlon es un derrotado desde su salida, por lo cual aun con la oportunidad del trabajo, se siente menoscabado y reducido con la sensación de que ni siquiera con la obtención de dólares, ha de lograr labrarse un destino digno en el país del norte. Esto se hace presente cuando se comunica con sus padres, pero les oculta el verdadero trabajo que lleva a cabo

-Hoy comienzo a trabajar.

-Siquiera, hijo, ¿y eso en qué?

Ya había planeado una respuesta que no les doliera.

-Pues de mesero, como todo el mundo.

Como todos los que nos habíamos ido y habíamos llegado a limpiar baños, pero mentíamos y hablábamos de la prosperidad, de nuestros triunfos y de la realización del sueño gringo, y si bien teníamos trabajo y la oportunidad de acariciar algunos dólares antes que los gastos se los llevaran, estábamos más jodidos que cuando salimos porque además nos sentíamos solos, estábamos solos, náufragos en pleno Nueva York.

- ¿Y por qué más bien no lo piensas y te devuelves?

-¿A qué, mamá? Aquí voy a estar bien (Franco, 2008, p. 107)

Las condiciones de vida en Colombia, como en la mayoría de los países de América Latina, empuja, en este caso, a los personajes a emigrar. La explotación laboral en Colombia se vuelve insoportable, con salarios bajos y carencia de pago en algunas situaciones. Ello explica, en parte, la decisión de Reina y Marlon, aun cuando se puedan discutir también las intenciones cultas que también mueven al desplazamiento.

En ese mundo enorme y extraño, el encuentro con otros latinos les representa una posibilidad de confort, pues de alguna manera los acerca a las raíces. De tal forma

La Revista Estudios es editada por la Universidad de Costa Rica y se distribuye bajo una Licencia Creative Commons Atribución-NoComercial-CompartirIgual 3.0 Costa Rica. Para más información envíe un mensaje a 
Especial: Profesores de Estudios Generales Investigan

lo siente Marlon, y por ello logra asimilarse, por lo menos no de manera tan cruenta como cuando llega y debe huir.

El juego del pasado y el presente va estableciendo la historia de encuentro, viaje y desencuentro que viven Marlon y Reina. Es la construcción de lo que representa la dureza de la vida del migrante en la nación en la cual no es aceptado por completo, y ello se nota en su devenir.

El primer lugar en el cual vive Marlon, un edificio viejo, es luego demolido, para dar paso a la idea del progreso deshumanizado que este señala, pues significa el despojo de los pobres para dar lugar a construcciones dedicadas a otros fines. Mientras tanto, sobrevive para tratar de encontrar a su novia, y la gran ciudad parece esconderla, aun cuando sea esta la que no se muestra.

Nueva York es el espacio monstruoso y devorador. Marlon siente el despojo al cual es sometido, y no puede evitar la idea de vivir la impresión vital de un mundo que es hostil siempre para con él, desolado, violento, brutal:

A veces me sucedía, a cada rato me vuelve a suceder que siento encima todo el peso de Nueva York. Sus millones de habitantes, las moles de cemento, hierro y cristal, sus toneladas de basura, su tiempo y su afán, el caudal de mierda de las alcantarillas, la demencia y la sangre pasan sobre mí como una aplanadora manejada por Dios (Franco, 2008, p. 135)

Se desprende con claridad de la cita anterior la idea pesimista, derrotista y asfixiante que posee Marlon con respecto a su entorno. No tiene lugar. Vegeta por ese mundo. Es el migrante sin asidero, el que llega y se siente Aún más despojado y más solitario.

Nueva York es la manifestación de una mentira impuesta a Marlon desde antes de llegar. Solo el encuentro con la verdad le desdibuja la fantasía de un mundo inexistente. La promesa de una mañana mejor, más digno se le cae a pedazos,

\section{(ब) $\odot \odot$}

La Revista Estudios es editada por la Universidad de Costa Rica y se distribuye bajo una Licencia Creative Commons Atribución-NoComercial-CompartirIgual 3.0 Costa Rica. Para más información envíe un mensaje a revistaestudios.eeg@ucr.ac.cr. 


\section{Especial: Profesores de Estudios Generales Investigan}

mientras va descubriendo la esencia de la fealdad representada en la mole de edificios, calles, rótulos, suciedad y caos.

Nueva York es la mentira, es la máscara, es la carencia, es la paradójica inaccesibilidad de lo grato, y el acceso a lo grotesco que esta ofrece para el extraño, por lo menos en el texto. La máscara es lo que propicia el viaje, la búsqueda de una verdad inexistente pero seductora

Nos reímos atrevidamente como si ya estuviéramos en el Nueva York que nos inventamos, el que inventó Reina para mí, para que la acompañara a donde creía yo que estaba la felicidad (Franco, 2008, p. 140)

La degradación de Colombia como país, la culpa asumida de Marlon, y la idea clara de que es producto de la incompetencia de él y de los miles que lo abandonan o permanecen en él sin hacer algo por mejorarlo. Paraíso Travel es la compañía fantasma, clandestina que los transporta en un viaje prometido con dignidad, pero que se convierte en una travesía infernal.

El infierno neoyorkino, ante la visión de Marlon, se convierte en la eterna promesa para Reina, aun cuando esta tampoco la pase de la mejor forma.

La búsqueda de esta en medio de la ciudad "infinita" en la cual se encuentra, se convierte para los demás en una muerte simbólica, la cual no acepta Marlon. La ciudad devora y esconde, Reina parece hallarse entre las sombras, oculta a la mirada de su novio.

El migrante no entiende, de acuerdo con la reflexión de los personajes, porqué no se devuelve, pero de igual forma tampoco tiene claro por qué deciden quedarse. Es la actitud del coprófago, como apunta Roger Pena, uno de los tantos personajes que circula por la novela.

Marlon no se acostumbra a vivir en Nueva York, sino que se resigna, según sus palabras. Se siente el parásito que vive en las entrañas de la bestia, se alimenta 
Especial: Profesores de Estudios Generales Investigan

de esta, come de sus entrañas, pero procurar no provocar a ese monstruo que le representa la jungla de cemento. De nuevo, es la concepción del migrante sin arraigo, que también vive en conflicto con su pasado.

A diferencia de este, Óscar, con el paso del tiempo, lo mismo que algunos otros, logran salir adelante, claro está, en el exilio, como ocurre con el caso de Yunior, quien narra la novela, y es un antiguo novio de Dolores (Lola), el cual se convierte en profesor y escritor gracias a la influencia de Oscar, lo que de alguna manera establece su legado en la figura del amigo.

En definitiva, la maldición que empuja a lo fatídico en la familia, no acaba con la muerte de Oscar, sino que se ciñe en las figuras de la madre y la hermana. La primera muere de cáncer, después de haber vencido un primer ataque. Muere derrotada, envejecida, débil, cansada, y sin esperanza para seguir luchando, lo que confirma la suerte de los suyos como sujetos incapaces de vencer la adversidad que se cierne sobre ellos, ya sea dentro de la isla o en el exilio como migrantes. Dolores deambula fuera de la isla, lejos, muy lejos, en busca de una salida a una vida sin horizontes, los cuales se define4 en un intento desesperado por rehacerse en otro lugar. Regresa, luego va a los Estados Unidos, pero nunca logra la paz. Rehúsa volver a su país, se va a Miami, y allí parece quedarse.

El crimen de Óscar queda impune, pues lo cubre la ley de República Dominicana, que oculta al asesino detrás del acto: el novio de lbón, y los sicarios que lo ejecutaron. De nuevo, ni siquiera en su muerte recibe un verdadero acto de justicia.

El final guarda un carácter pesimista: nada termina, nada tiene solución final, en clara alusión a la historia de dolor que han vivido y que siguen viviendo, pero también en torno a la maldición. Mientras existan descendientes de los León, el fukú seguirá golpeando como el legado maldito de Trujillo.

\section{(c) (i) (-)}

La Revista Estudios es editada por la Universidad de Costa Rica y se distribuye bajo una Licencia Creative Commons Atribución-NoComercial-CompartirIgual 3.0 Costa Rica. Para más información envíe un mensaje a revistaestudios.eeg@ucr.ac.cr. 


\section{Especial: Profesores de Estudios Generales Investigan}

Su última carta es la confesión de su permanencia final con Ibón, con la cual logró rapar después de esperar toda su vida. Ese es su triunfo final. Der igual manera su encuentro postrero le representa lo sublime de las relaciones con otra persona: peinarla, mirarla caminar desnuda, tender o descolgar su ropa íntima, tenerla en los regazos y sentir su rostro contra el de ella. Es, tal como él lo escribe: "iThe beauty! ¡The beauty!"

Es la razón por la que vivió, y es la razón por la cual murió, otorgándole un sentido a ese final. Es su último viaje, como auto promesa cumplida.

Finalmente, el título de la novela es una ironía con respecto a la maravillosa vida de Óscar Wao. Es también, el símbolo del pueblo reprimido, y acosado, que busca en los sueños desesperados la forma de vivir y sobrevivir en medio de la abyección.

Mientras que en la novela de Franco el colombiano en general, lo mismo que el migrante, sin importar de dónde provengan, pasan por una crisis en ese mundo al cual se insertan o, más claramente, en ese mundo que lo devora

Se refería a nosotros, los parias del mundo, los que tenemos el pelo y los ojos del mismo tono oscuro, los que no somos más altos que una nevera, los descendientes directos del simio, con narices anchas y bembas coloradas. Lo decía Roger Pena como si el mundo se dividiera en seres humanos y colombianos (Franco, 2008, pp. 154-155)

La búsqueda que alimenta el propósito de Marlon, adquiere una dimensión diferente cuando logra mirar a Reina, en un encuentro totalmente fortuito, casual, importantísimo para él, no para Reina, cuando los trenes en los cuales viajan les permite mirarse. Marlon reinicia su búsqueda, pero se da cuenta, sin admitirlo plenamente, que esta no lleva a cabo la búsqueda de él. Acaso la inaccesibilidad de Reina sea simbólica: la búsqueda Marlon es el sentido de un sinsentido, hallar a Reina es darle sentido a la ciudad que se oculta, que se esconde, que no desea

\section{(a) $\mathbb{Q} \Theta($}

La Revista Estudios es editada por la Universidad de Costa Rica y se distribuye bajo una Licencia Creative Commons Atribución-NoComercial-CompartirIgual 3.0 Costa Rica. Para más información envíe un mensaje a revistaestudios.eeg@ucr.ac.cr. 


\section{Especial: Profesores de Estudios Generales Investigan}

ser hallada, y que no desea hallarlo. Reina es el símbolo de la ciudad que se escapa y a la cual no se puede acceder.

El viaje de Marlon es un trayecto de dolor, que implica y venir de Colombia a Estados Unidos y viceversa, sin que ello implique un alivio. Por eso no regresa. Por eso desea regresar. Esta derrotado, y quizás la aparición de Milagros, nombre simbólico, trae una transformación a su vida, sin que se decida a admitirlo.

Es por ello que no se resigna a vivir en Nueva York, pero también se da cuenta de que la muerte y la carencia de futuro se hallan en Colombia, sin dejar de lado el funesto viaje que implica ir de un lugar al otro cuando se es migrante e ilegal

El asunto me seguía sonando mal. Recordé lo que me dijo Carlitos: por allá han matado a mucha gente; los atracan, violan a las mujeres, se roban a los niños, muchos se ahogan al pasar el río. Yo ya se lo había dicho a Reina, pero ella me desafió: ¿y es que aquí no matan?, ¿aquí no violan?, ¿aquí no secuestran niños? Prefiero morir intentándolo, dijo, a que me maten aquí cruzada de brazos y sin ninguna razón. Yo siempre me quedaba sin argumentos para alegarle. Qué podía decir de un país donde en cualquier esquina está acechando la tragedia, lista para enlutarte (Franco, 2008, p. 159)

Por ello, termina por emprender el viaje, aun cuando sepan que la esperanza es lo único que les queda, pues la seguridad es un azar en medio de las vicisitudes que deberán enfrentar a lo largo del camino de miles de kilómetros. Y que ni siquiera la llega es señala de garantía de que han de lograr los sueños perseguidos.

Aunado a lo anterior, a ese proceso de ir de un lugar a otro, a renunciar a la patria (al pasado, incluso) para asimilarse a otro entorno, sin que ello garantice el objetivo fundamental, una ambigüedad puede devenir en algunos de los personajes, tal como le ocurre a Reina. El color distinto de sus ojos es síntoma de esa manifestación, pues como lo dice Roger Pena, cuyo verdadero nombre es Rogelio Peña, Reina, al tener un ojo de un color y otro de otro color, en verdad manifiesta tener un ojo colombiano y otro gringo. La risa que le adviene al 


\section{Especial: Profesores de Estudios Generales Investigan}

personaje ante su comentario, no deslinda, sin embargo, que, pese al tono humorístico que de él proviene, ciertamente grafica la ambivalencia de lo que representa Reina como personaje ante los demás, y ante Marlon mismo, hacia el final del texto.

La paradoja de lo que representa el título, el viaje al paraíso, es más bien un viaje al infierno, a la explotación a que son sometidos, no solo durante el viaje, sino incluso durante la llegada a Estados Unidos. Es el sino funesto que parece acompañar a la mayoría, si bien algunos "logran" paliar su situación de mejor forma.

Huyen de Latinoamérica porque es la estampa de la pobreza, como apunta Marlon, y en ese periplo se van despojando de todo, hasta de los pasaportes y documentos que indiquen quiénes son y de dónde provienen. Es la pérdida simbólica no solo de unos papeles que les confieren o les reafirman una determinada identidad, sino de todo un proceso que los define como colombianos, como latinoamericanos, como sujetos y los despoja de parte del pasado y de la vida.

Por lo anterior, y ya en Estados Unidos, Marlon es incapaz de despojarse de sus inseguridades y miedos. Estos, como él mismo lo dice, los lleva incrustados en el cuerpo, no solo estando allí, sino incluso en un potencial regreso a Colombia, pues son parte de miedos ancestrales de los que no puede prescindir aunque así lo desea.

Es precisamente el viaje que realizan desde Colombia hasta Estados Unidos lo que le permite a Marlon darse cuenta de que son sujetos derrotados. A pesar de que no lo acepte de tal manera, Reina participa de esa derrota, pues su trabajo la minimiza en un espacio en el cual la promesa de un futuro mejor parece no aflorar. Marlon no se cuestiona el éxito, pues no lo lleva consigo, ni siquiera se lo plantea.

\section{(C) $(00$}

La Revista Estudios es editada por la Universidad de Costa Rica y se distribuye bajo una Licencia Creative Commons Atribución-NoComercial-CompartirIgual 3.0 Costa Rica. Para más información envíe un mensaje a revistaestudios.eeg@ucr.ac.cr. 


\section{Especial: Profesores de Estudios Generales Investigan}

Pero sí manifiesta su espíritu derrotista, ese sinsabor existencial que lleva consigo por siempre y que ni siquiera el reencuentro con Reina logra paliar.

El dinero que pierden o les roban a lo largo del camino, es parte del desencanto por la oferta de un viaje que no es más que un verdadero robo, según lo conciben, pues el dinero que pagan no les garantiza estadías en lugares adecuados, ni alimentación, ni adelantos por transporte. Ello termina por consolidar el total desacierto que los embarga y que los convierte en parias a lo largo de todo el viaje.

El migrante se convierte, en esta novela en particular, en un sujeto que queda atado a los vaivenes de quienes lo llevan durante la travesía, en su viaje físico, además de su propio viaje de reconocimiento y autoconocimiento. Se siente despojo y miseria durante esa travesía de dolor.

Ese viaje les permite conocer la miseria también de otros, lo mismo que la alegría, a pesar de que su trayecto carece de alegrías. El triunfo es la llegada, con las implicaciones y las marcas que el cuerpo y el alma les va dejando en el camino. Los bestializan, los transportan como ganados, o en medio de la madera de un camión lleno de troncos, los cuales están huecos, por lo que también son cosificados. Es un viaje que denigra, que degrada y que los va construyendo, no como personas, sino como cosas.

En algún momento, a punto de llegar, cuando Marlon recuerda su viaje y lo narra a Milagros, este le cuenta que un zorro tenía mejor consideración y respeto que el que recibían ellos durante el recorrido. A la vez, cuenta a Milagros que en otro momento los arreaban como si fueran vacas, lo cual les daba la clara certeza de lo que representaban para aquella gente. Todo ello al amparo de lo que significaba la compañía de viajes Paraíso Travel, la cual era más una farsa que una verdadera

\section{(a) $\mathbb{Q} \Theta($}

La Revista Estudios es editada por la Universidad de Costa Rica y se distribuye bajo una Licencia Creative Commons Atribución-NoComercial-CompartirIgual 3.0 Costa Rica. Para más información envíe un mensaje a revistaestudios.eeg@ucr.ac.cr. 
Especial: Profesores de Estudios Generales Investigan

compañía de viajes, y la ironía del nombre de nuevo se pone de manifiesto como burla hacia los viajantes.

Finalmente, en ambas novelas, la culminación del viaje y la búsqueda desesperada en procura de Reina, le da la certeza a Marlon de lo que significa esta como tal: deja de lado su ambigüedad cuando finalmente la encuentra y descubre que ahora sus ojos son de igual color, y ha renunciado a su pasado; de allí que no tenga contacto con su patria ni con su padre. A Óscar, por su parte, le permite vislumbrar un sueño de triunfo al final de su vida, aun cuando le cueste la muerte.

Reina encuentra a su madre Raquel, verdadero objetivo de su viaje, la cual es alcohólica, vive en la miseria, sin futuro alguno, mientras ahora Reina se prostituye en lo que representa el desenmascaramiento de su sueño americano. Necesita dinero y es la única forma de ganarlo. Ahora Reina le representa, en definitiva, la diferencia, el desencuentro y el desencanto. La interpela, mientras esta le responde con gritos e improperios. Ahora es distinta, lejana, inaccesible, pero también extraña para Marlon. Su reencuentro es el inicio de la separación. La distancia que se manifiesta entre ambos, el cambio en términos de gradación de Marlon, y el desenmascaramiento que realiza Reina, al evidenciarse tal como debió haber sido siempre, los pone en contradicción. La búsqueda termina. Ahora es Marlon quien la abandona. Es el migrante golpeado el que ejerce su posibilidad de liberación.

La separación es inevitable. Marlon se encuentra a sí mismo, Reina, por su parte, se pierde a sí misma; es la paradoja final del desencuentro entre dos migrantes con caminos diferentes, antagónicos.

El triunfo de Óscar es la pérdida de su virginidad y el logro del amor, pero también su logro como escritor, como migrante, como hombre y como soñador. Ante tal 
perspectiva, parece adquirir un cierre de mayor optimismo que en la novela de Franco.

\section{Bibliografía}

Arango, Joaquín (2003). "La explicación teórica de las migraciones: luz y sombra". Migración y desarrollo, número 1 (Zacatecas). Octubre 2003. https://www.redalyc.org/articulo.oa?id=66000102

Aruj, Roberto S. (2008). "Causas, consecuencias, efectos e impacto de las migraciones en Latinoamérica". Papeles de población, vol. 14, número 55 (Toluca). Enero-marzo.

Dekocker, Katrien (2017). “La emigración venezolana como estrategia de reproducción social y su concepción en España entre 1998-2015: Factores determinantes.". Madrid: Instituto Universitario de Estudios sobre Migraciones/Universidad de Comillas.

File:///C:/Users/1001001153/Downloads/TD00241.pdf.

Díaz, Junot (2010). La breve y maravillosa vida de Óscar Wao. República Dominicana: Alfaguara.

Domínguez Mon, Ana. (2012). "Migraciones contemporáneas; aportes desde las Ciencias Sociales". Buenos Aires. Vol. 18, número 2. Ciudad Autónoma e Buenos Aires. $\quad$. Diciembre, 2012. http://wwwscielo.org.ar/scielophp?script=sci_arttext\&pid=S1853$001 \times 2012000200001$

Franco, Jorge (2008). Paraíso Travel. Colombia: Seix Barral.

\section{(c) (i) (ㅇ)}

La Revista Estudios es editada por la Universidad de Costa Rica y se distribuye bajo una Licencia Creative Commons Atribución-NoComercial-Compartirlgual 3.0 Costa Rica. Para más información envíe un mensaje a revistaestudios.eeg@ucr.ac.cr. 
ISSN 1659-3316

Especial: Profesores de Estudios Generales Investigan

Micolta León, Amparo (2005). "Teorías y conceptos asociados al estudio de las migraciones internacionales". Trabajo Social No. 7, (2005), pp. 59-76. () Revista del Departamento de Trabajo Social, Facultad de Ciencias Humanas, Universidad Nacional de Colombia. 